\title{
Clipping of a partially thrombosed giant PICA aneurysm associated with the anterior spinal artery
}

\author{
Gregory Glauser, Matthew Piazza, Ryan Dimentberg, Omar Choudhri
}

Neurosurgery, Hospital of the University of Pennsylvania, Philadelphia, Pennsylvania, USA

\section{Correspondence to} Mr Gregory Glauser; gregory.glauser@pennmedicine. upenn.edu

Accepted 26 September 2019

\section{DESCRIPTION}

This video 1 case presents some unique technical tenets for the microsurgical clipping of a giant posterior inferior cerebellar artery aneurysm. The patient described in this case was a 60 -year-old woman with a history of coil embolisation of a left vertebral artery aneurysm. The patient presented with headaches and mild left-sided blurry vision, which remained after prior embolisation. Cerebral angiography (figure 1) demonstrated interval coil compaction with marked increase in the aneurysm base, measuring $\sim 9.8 \times 7.2 \times 4.0 \mathrm{~mm}$

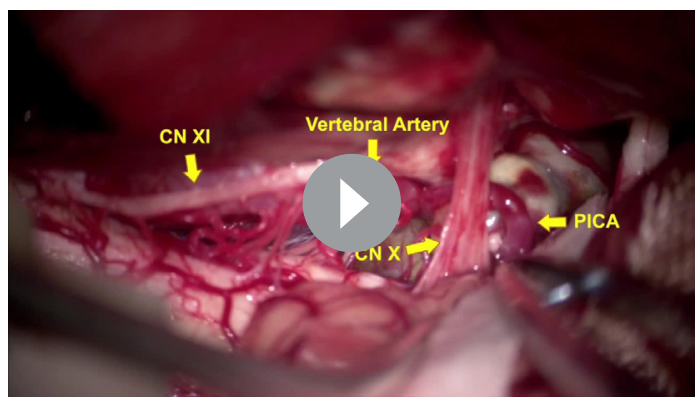

Video 1 PICA aneurysm; aneurysm clipping; giant aneurysm; cerebrovascular. PICA, posterior inferior cerebellar artery.

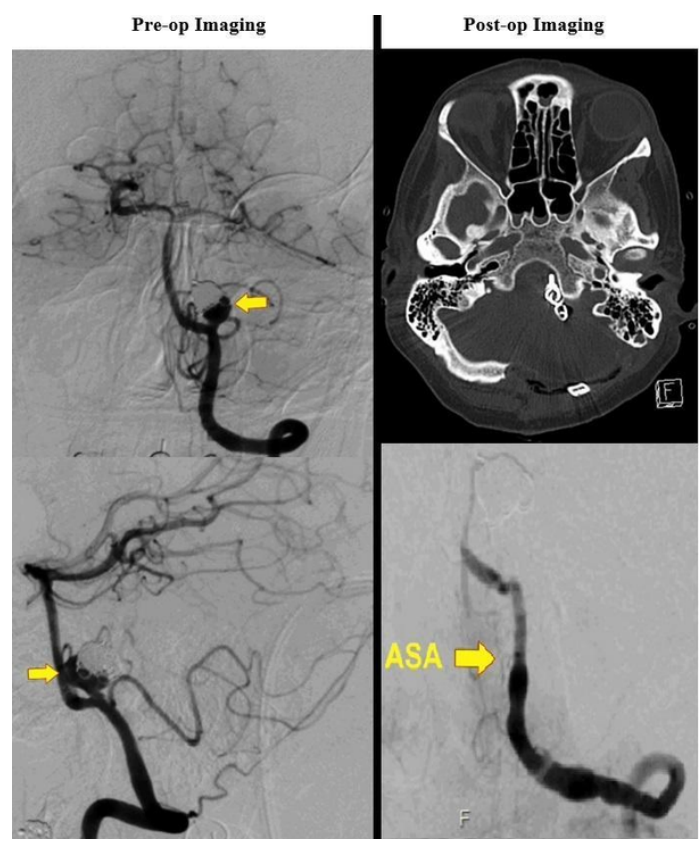

Figure 1 Preoperative and postoperative imaging.

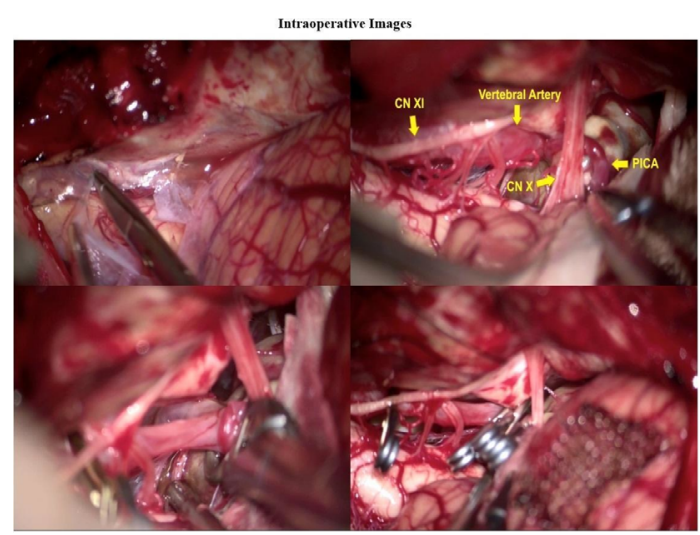

Figure 2 Intraoperative view of the operative field.

\section{Learning points}

- This case demonstrates the usefulness of far lateral craniotomy with transcondylar exposure for large posterior inferior cerebellar artery aneurysms.

- The video highlights the identification and preservation of the anterior spinal artery.

(figure 2). Alternative treatment options considered this patient included stent coiling, pipeline embolisation or left vertebral artery coil sacrifice. This case is valuable to the literature as it illustrates technical steps required for clipping of a large aneurysm using fenestrated clips and need for identification and preservation of anterior spinal artery.

Contributors All authors certify that they have each made a substantial contribution as to qualify for authorship as follows: OC and MP performed the procedure, $\mathrm{OC}$ provided video narration, GG and RD performed critical video editing and preparation for publication. All authors approved the final documents.

Funding The authors have not declared a specific grant for this research from any funding agency in the public, commercial or not-for-profit sectors.

Competing interests None declared.

Patient consent for publication Obtained.

Provenance and peer review Not commissioned; externally peer reviewed.

ORCID iD

Omar Choudhri http://orcid.org/0000-0002-8311-2336 
Copyright 2019 BMJ Publishing Group. All rights reserved. For permission to reuse any of this content visit https://www.bmj.com/company/products-services/rights-and-licensing/permissions/

BMJ Case Report Fellows may re-use this article for personal use and teaching without any further permission.

Become a Fellow of BMJ Case Reports today and you can:

- Submit as many cases as you like

Enjoy fast sympathetic peer review and rapid publication of accepted articles

Access all the published articles

Re-use any of the published material for personal use and teaching without further permission

Customer Service

If you have any further queries about your subscription, please contact our customer services team on +44 (0) 2071111105 or via email at support@bmj.com.

Visit casereports.bmj.com for more articles like this and to become a Fellow 